\title{
Physiological responses of Eucalyptus urophylla young plants treated with biostimulant under water deficit
}

\author{
Respostas fisiológicas de plantas jovens de Eucalyptus urophylla tratadas com \\ bioestimulante sob déficit hídrico
}

\author{
Rayka Kristian Alves Santos ${ }^{\mathrm{I}}$, Paulo Araquém Ramos Cairo ${ }^{\mathrm{II}}$, Romário Pereira \\ Barbosa $^{I I I}$ Janderson de Jesus Lacerda ${ }^{\text {IV }}$, Caio da Silva Mafra Netov ${ }^{\mathrm{V}}$, Theilon \\ Henrique de Jesus MacedovI
}

\begin{abstract}
Biostimulants consist of a mixture of growth regulators that, when they are sprayed on plants, act on hormonal balance, enhancing its development. Stimulate ${ }^{\circledR}$ is a biostimulant composed by indole butyric acid $(0.005 \%)$, kinetin $(0.009 \%)$ and gibberellic acid $(0.005 \%)$ which promotes root growth, improves water and nutrients uptake, and helps restore plant hormonal balance. This research was based on the hypothesis that Stimulate ${ }^{\circledR}$ spraying can be an alternate way to mitigate negative effects of soil water-limiting on plant growth. The experimental work was performed in greenhouse and aimed to evaluate physiological responses of young plants of Eucalyptus urophylla sprayed with different Stimulate ${ }^{\circledR}$ concentrations and submitted to the following irrigation regimes: full, partial and no irrigation. Leaf water potential, relative water content, net photosynthesis, plant height and main root length were measured. Under water-limited conditions, plants sprayed with Stimulate ${ }^{\circledR}$ showed higher net photosynthesis and relative water content had a less decrease, due to osmotic adjustment. Spraying with Stimulate ${ }^{\circledR}$ also provided greater plant height and longer main root length in plants under water deficit. We conclude that the use of Stimulate ${ }^{\circledR}$ can be a viable option to mitigate negative water stress physiological effects in young plants of Eucalyptus urophylla, helping to partially maintain the plant growth under waterlimited conditions.
\end{abstract}

Keywords: Woody plants; Plant growth regulators; Drought; Water stress

\section{Resumo}

Os bioestimulantes consistem em uma mistura de reguladores de crescimento que, quando aplicados nas plantas, atuam no equilíbrio hormonal, melhorando seu desenvolvimento. Stimulate ${ }^{\circledR}$ é um bioestimulante composto por ácido indolbutírico $(0,005 \%)$, cinetina $(0,009 \%)$ e ácido giberélico $(0,005 \%)$, que promove o crescimento das raízes, melhora a absorção de água e nutrientes e ajuda a restaurar o equilíbrio hormonal das plantas. Esta pesquisa foi baseada na hipótese de que a pulverização com Stimulate ${ }^{\circledR}$ pode ser uma forma alternativa de mitigar os efeitos negativos da limitação da água no solo para o crescimento das plantas. O trabalho experimental foi realizado em casa de vegetação e objetivou avaliar respostas fisiológicas de plantas jovens de Eucalyptus urophylla pulverizadas com diferentes concentrações de Stimulate ${ }^{\circledR}$ e submetidas aos seguintes regimes de irrigação: total, parcial e sem irrigação. Foram mensurados o potencial hídrico foliar, o teor relativo de água, a fotossíntese líquida, a altura de plantas e o comprimento da raiz principal. Sob condições de limitação hídrica, as plantas pulverizadas com Stimulate ${ }^{\circledR}$ apresentaram maior fotossíntese líquida, e o conteúdo relativo de água teve menor decréscimo, devido ao ajuste osmótico. A pulverização com Stimulate ${ }^{\circledR}$ também proporcionou maior altura de planta e maior comprimento de raiz principal em plantas sob deficit hídrico. Concluiu-se que o uso de Stimulate ${ }^{\circledR}$ pode ser uma opção viável para mitigar os efeitos fisiológicos negativos do estresse hídrico em plantas jovens de Eucalyptus urophylla, ajudando a manter parcialmente o crescimento das plantas sob condições de limitação hídrica.

Palavras-chave: Plantas lenhosas; Reguladores de crescimento vegetal; Seca; Estresse hídrico

\footnotetext{
Engenheira Agrônoma, Drạ., Pesquisadora Autônoma, Estrada do Bem-querer, Km 4, CEP 45031-900, Vitória da Conquista (BA), Brasil. raykakristian@yahoo.com.br (ORCID: 0000-0003-2232-8288)

Engenheiro Agrônomo, Dr., Professor do Departamento de Fitotecnia e Zootecnia, Universidade Estadual do Sudoeste da Bahia, Estrada do Bemquerer, Km 4, CEP 45031-900, Vitória da Conquista (BA), Brasil. pcairo@uol.com.br (ORCID: 0000-0002-3619-7867)

III Engenheiro Agrônomo, MSc., Pesquisador Autônomo, Estrada do Bem-querer, Km 4, CEP 45031-900, Vitória da Conquista (BA), Brasil. romariogeoref@gmail.com (ORCID: 0000-0003-2789-4318)

IV Engenheiro Agrônomo, MSc., Doutorando do Programa de Pós-Graduação em Produção Vegetal, Universidade Estadual de Santa Cruz, Campus Soane Nazaré de Andrade, Rod. Jorge Amado, km 16, Salobrinho, Pavilhão Max de Menezes, CEP 45.662-900, Ilhéus (BA), Brasil.

janderson.lacerda@gmail.com (ORCID: 0000-0002-2288-8069)

Engenheiro Florestal, Pesquisador Autônomo, Suzano S. A., Rod. BR 101, Km 49 (trevo), CEP 29960-000, Conceição da Barra (ES), Brasil. caio_mafraflorestal@yahoo.com.br (ORCID: 0000-0003-2108-8024)

Engenheiro Florestal, Mestrando do Programa de Pós-Graduação em Ciências Florestais, Universidade Estadual do Sudoeste da Bahia, Estrada do Bem-querer, Km 4, CEP 45031-900, Vitória da Conquista (BA), Brasil. theilonhenrique@gmail.com (ORCID: 0000-0003-4306-4832)
} 


\section{Introduction}

Species from Eucalyptus genus produce a type of wood that is mainly used as raw material for charcoal, pulp, paper, furniture and railway sleepers. In addition, eucalyptus plants also produce essences and essential oils (VENTURIN et al., 2014).

In Brazil, Eucalyptus plantations are found mainly in regions with annual precipitation above $1000 \mathrm{~mm}$. However, due to the Brazilian climatic diversity, these plantations have expanded to even dry regions, with annual rainfall below $1000 \mathrm{~mm}$ and unstable rainfall distribution (VENTURIN et al., 2014). In the southwestern of Bahia state, where drought is recorrent, several farmers have planted Eucalyptus urophylla, a tolerant species to water-limited conditions (FERNANDES; CAIRO; NOVAES, 2015).

According to Whitehead and Beadle (2004), who have studied physiological aspects of plant-soil-water relationship in Eucalyptus, the water consumption per biomass unity of this specie is equivalent to the any other forest specie. The increasing demand for wood, however, has led to the expansion of Eucalyptus cultivation to many regions with wide climatic diversity. In countries where Eucalyptus species are introduced, it is necessary to evaluate the water consumption and biomass productivity relationships, especially in water-limited regions (ALBAUGH; DYE; KING, 2013). Thus, developing technologies to mitigate negative water deficit effects on Eucalyptus growth and productivity after seedlings planting in the field has been a constant demand to researchers.

Phytomass partitioning of eucalyptus can also be affected by water deficit promoting root growth rather than shoot growth (BRUNNER et al., 2015), thus optimizing water uptake, while concomitantly minimizing water loss from transpiration. The root-to-shoot increasing, in turn, is influenced by the severity and lenght of the water stress (POORTER et al., 2012). Hormones have been shown to play an important role in growth regulation and adjusting root-to-shoot ratio to water availability (CLAEYS; INZÉ, 2013; TAIZ et al., 2017).

Stimulate ${ }^{\circledR}$ is a biostimulant composed of the following plant regulators: indole butiric acid - IBA (0.005\%), which becomes to indole acetic acid and promotes cell elongation; kinetin $(0.009 \%)$, a cell division promoting cytokinin; and gibberelic acid $(0.005 \%)$, which participates in several plant growth metabolic pathways. Stimulate ${ }^{\circledR}$ promotes root growth, increasing water and nutrients uptake, besides to favor the plant hormonal balance (SANTOS, 2004). However, relationship between Stimulate ${ }^{\circledR}$ effects on plant growth and its hability to mitigate water stress is still poorly known.

This research was based on the hypothesis that Stimulate ${ }^{\circledR}$ spraying can be an alternate way to mitigate negative effects of soil water-limiting on plant growth. Thus, a greenhouse experimental work was performed with aim to evaluate physiological responses of young plants of Eucalyptus urophylla sprayed with different Stimulate ${ }^{\circledR}$ concentrations and submitted to three irrigation regimes (full, partial and no irrigation).

\section{Materials and methods}

The experiment was started in September 2014, in greenhouse at the State University of Southwest Bahia, in Vitória da Conquista, Brazil. Eucallyptus urophylla seedlings (clone AEC 144) were produced in small tubes $\left(54 \mathrm{~cm}^{3}\right)$ containing the following substrate: bovine manure (40\%), vermiculite (40\%) and coconut husk powder (20\%) (OLIVEIRA JÚNIOR; CAIRO; NOVAES, 2011). Seedlings 100 days old, four pair of leaves, $30 \mathrm{~cm}$ height and $8 \mathrm{~mm}$ lap diameter were planted in $16 \mathrm{~L}$ pots (one plant pot ${ }^{-1}$ ), containing yellow oxysol, sandy-clay texture and fertilization based on soil chemical analysis and nutrient demand of Eucalyptus (RIBEIRO; GUIMARÃES; ALVAREZ, 1999). The mean values of temperature and relative humidity within the greenhouse during the experimental period were $25.2^{\circ} \mathrm{C}$ and $78.3 \%$, respectively.

Treatments were arranged in a $5 \times 3$ factorial (five Stimulate ${ }^{\circledR}$ concentrations and three 
irrigation regimes), with five replicates in a completely randomized design. The Stimulate ${ }^{\circledR}$ concentrations were $0,10,20,30,40 \mathrm{~mL} \mathrm{~L}^{-1}$. The irrigation regimes were full (WR 100\%), partial (WR 50\%) and no irrigation (WR 0\%).

Stimulate ${ }^{\circledR}$ was sprayed only on shoots, at 8-9 h a.m., using a manual pressure sprayer, with no plant oil added (DANTAS et al., 2012). Each plant was sprayed with $50 \mathrm{~mL}$ of Stimulate ${ }^{\circledR}$ at 3th and 13th days after planting. A plastic film was used to cover each pot, just to avoid possible deposition of residues of the Stimulate ${ }^{\circledR}$ sprayings on soil surface.

Irrigation regimes were implemented on the 10th day after planting, i.e. between the first and the second Stimulate ${ }^{\circledR}$ spraying. Full irrigated regime was considered as soil at field capacity, which was determined by the direct gravimetric method (EMBRAPA, 1997). Soil water content was determined from the average water content of four $16 \mathrm{~L}$ pots filled only with soil (no plants) fully watered, followed by natural drainage for $24 \mathrm{~h}$. Soil moisture was maintained almost on field capacity for $100 \%$ WR, and in half, for WR $50 \%$.

On the 15th day after the establishment of the irrigation regimes, when the leaves of the plants under WR 50\% and 0\% showed signs of wilting, the following variables were measured: leaf water potential, relative water content, net photosynthesis, plant height and main root length.

A pressure bomb was used to measure leaf water potential (SCHOLANDER et al., 1965) in ripe leaves in the middle of the canopy, at $5 \mathrm{~h}$ a.m., when the leaf and soil water potentials are usually considered to be similar (SAITO et al., 2003; COSTA E SILVA et al., 2004). These same leaves were referred for relative water content measurements, following Weatherley (1950), which described RWC = (fresh mass - dry mass) / (turgid mass - dry mass) $x$ 100. Net photosynthesis measurements were performed by an infrared gas analyser (IRGA LI-6400, LI-COR ${ }^{\circledR}$, Nebraska/ USA), at 9-11 h a.m., in ripe leaves in the middle of the canopy. Firstly, plants were exposed to artificial irradiance with $940 \mathrm{mmol}$ fotons $\mathrm{m}^{-2} \mathrm{~s}^{-1}$, similar to that light saturation line used by Silva et al. (1998) in Eucalyptus citriodora and Eucalyptus grandis, which ranged from 800 to 1.000 mmol fotons $\mathrm{m}^{-2} \mathrm{~s}^{-1}$ (SILVA et al., 1998). A graded ruler was used to plant height and main root length measurements. Main root was referred as only the one with the largest length.

Data were submitted to normality of residues and homogeneity of variances. Analysis of regression were performed by SISVAR 5.0 program when differences among treatments were found.

\section{Results and discussion}

Stimulate ${ }^{\circledR}$ concentrations (C), as an isolated factor, had a significant effect on the variables, except in relation to the leaf water potential. Irrigation regimes (WR), in turn, also significantly affected the variables, except in relation to net photosynthesis. The effects of interaction (C) $\mathrm{x}(\mathrm{WR})$, however, led to significant differences for all variables evaluated (Table 1).

Concerning the $(C) \times(W R)$ interaction, Stimulate ${ }^{\circledR}$ concentrations led to no significant differences on leaf water potential either in plants under WR $50 \%$ or under $100 \%$ (-0.59 and -0.46 $\mathrm{MPa}$, respectively). Under non-irrigated conditions, however, leaf water potentials of sprayed plants with Stimulate ${ }^{\circledR}$ were lower than that non-sprayed plants. Stimulate ${ }^{\circledR} 30 \mathrm{~mL} \mathrm{~L}{ }^{-1}$ led to lowest leaf water potential (-0.69 MPa) under WR 0\% (Figure 1).

Under non-irrigated regime, as well as under WR 50\%, the relative water contents were higher in plants sprayed with Stimulate ${ }^{\circledR}$. Under non-irrigated regime, the highest relative water content $(58.34 \%)$ was reached in plants sprayed with Stimulate ${ }^{\circledR} 30 \mathrm{~mL} \mathrm{~L}^{-1}$, while under WR $50 \%$ this peak (65.9\%) was reached with Stimulate $20 \mathrm{~mL} \mathrm{~L}^{-1}$ (Figure 2). In these two water regimes, relative water content in plants sprayed with Stimulate ${ }^{\circledR}$ was higher than that in non-sprayed plants. This suggests that the fall intensity of plant relative water content under water-limited conditions may be soften by Stimulate ${ }^{\circledR}$. 
Table 1 - Analysis of variance and coefficient of variation $(\mathrm{CV})$ from leaf water potential $(\Psi \mathbf{w})$, relative water content $(\mathbf{R W C})$, net photosynthesis $(A)$, plant height $(\mathbf{H})$ and main root lenght $(R)$ data in young plants of Eucalyptus urophylla, clone AEC 144, sprayed with different Stimulate ${ }^{\circledR}$ concentrations $(C)$ and submitted to three irrigation regimes $(W R)$.

Tabela 1 - Análise de variância e coeficiente de variação $(C V)$ do potencial hídrico foliar $(\Psi w)$, teor relativo de água (RWC), fotossíntese líquida $(A)$, altura de planta $(\mathrm{H})$ e comprimento da raiz principal em plantas jovens de Eucalyptus urophylla, clone AEC 144, pulverizadas com Stimulate ${ }^{\circledR}$ em diferentes concentrações $(C)$ e submetidas a três regimes de irrigação (WR).

\begin{tabular}{|c|c|c|c|c|c|c|}
\hline \multirow{2}{*}{ Sources of Variation } & \multirow{2}{*}{$\begin{array}{l}\text { Degrees of } \\
\text { Freedom }\end{array}$} & \multicolumn{5}{|c|}{ Mean Squares } \\
\hline & & $\Psi_{w}$ & RWC & $\boldsymbol{A}$ & $\mathbf{H}$ & $\mathbf{R}$ \\
\hline Stimulate ${ }^{\circledR}$ concentrations $(C)$ & 4 & $0.01^{\mathrm{NS}}$ & $176.08^{*}$ & $28.30^{*}$ & $23.53^{*}$ & $310.44^{*}$ \\
\hline Irrigation regimes $(\mathrm{WR})$ & 2 & $0.23^{\star *}$ & $242.05^{*}$ & $9.90^{\mathrm{NS}}$ & $30.62^{*}$ & $84.91^{*}$ \\
\hline (C) $\mathbf{x}$ (WR) interation & 8 & $0.02^{* *}$ & $95.65^{*}$ & $16.00^{*}$ & $15.39^{*}$ & $106.76^{*}$ \\
\hline Error & 60 & 0.01 & 8.76 & 5.79 & 4.47 & 9.34 \\
\hline CV (\%) & & 18.70 & 6.30 & 12.45 & 5.82 & 7.61 \\
\hline
\end{tabular}

${ }^{*}$ F significant $(\mathrm{p}<0.05) ;{ }^{\text {NS }}$ Non significant.

Figure 1 - Leaf water potential $(\Psi w)$ in young plants of Eucalyptus urophylla, clone AEC 144, sprayed with different Stimulate ${ }^{\circledR}$ concentrations, under non-irrigated regime (WR 0\%). )

Figura 1 - Potencial hídrico foliar $\left(\Psi_{\mathrm{w}}\right)$ em plantas jovens de Eucalyptus urophylla, clone AEC 144, tratadas com Stimulate ${ }^{\circledR}$ em diferentes concentrações, sob regime não irrigado (WR 0\%).

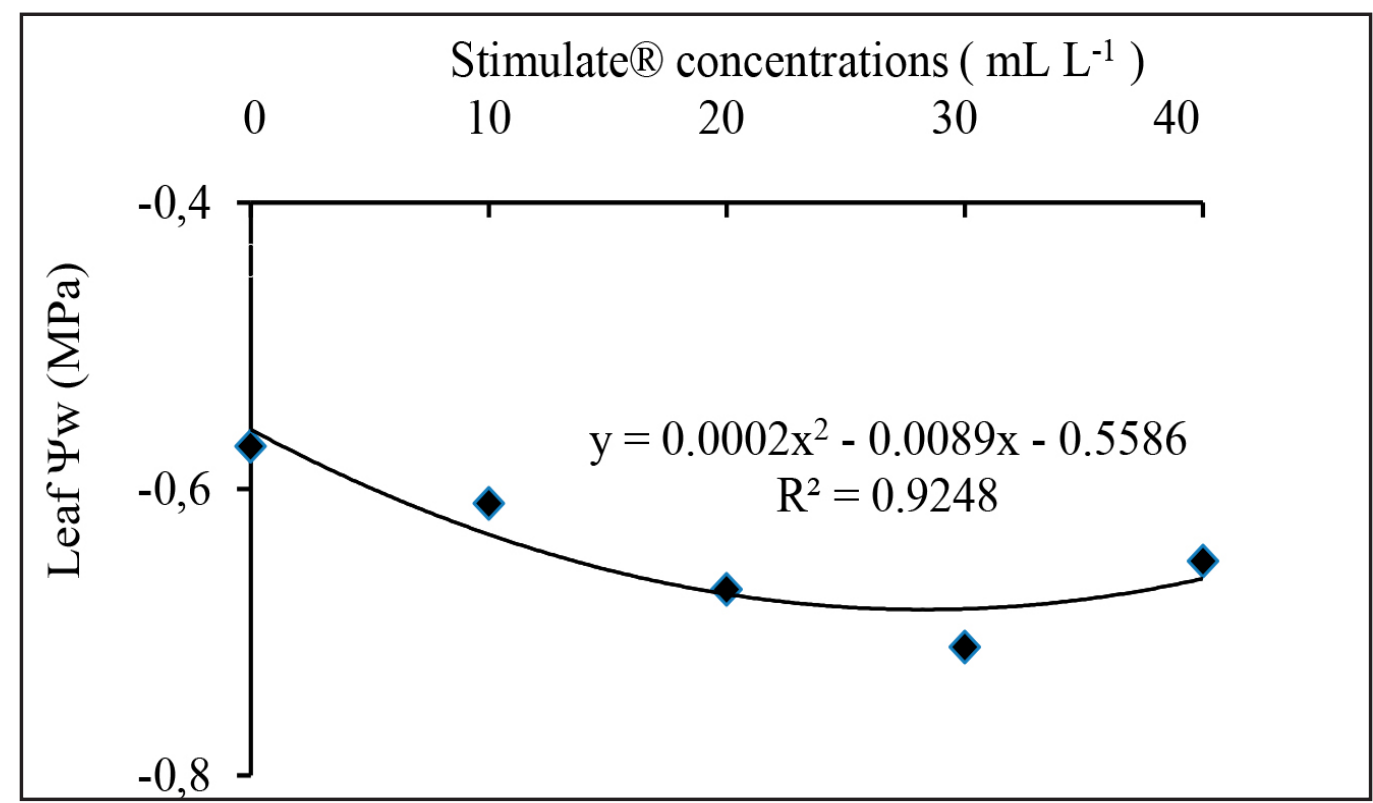

Source: Santos, Cairo, Barbosa, Lacerda, Mafra Neto and Macedo (2019

Fonte: Santos, Cairo, Barbosa, Lacerda, Mafra Neto e Macedo (2019) 
Figure 2 - Relative water content (RWC) in young plants of Eucalyptus urophylla, clone AEC 144, sprayed with different Stimulate ${ }^{\circledR}$ concentrations, under non-irrigated (WR 0\%) and WR $50 \%$ regimes.

Figura 2 - Teor relativo de água (RWC) em plantas jovens de Eucalyptus urophylla, clone AEC 144, pulverizadas com Stimulate ${ }^{\circledR}$ em diferentes concentrações, sob regimes não irrigado (WR $0 \%)$ e WR $50 \%$.

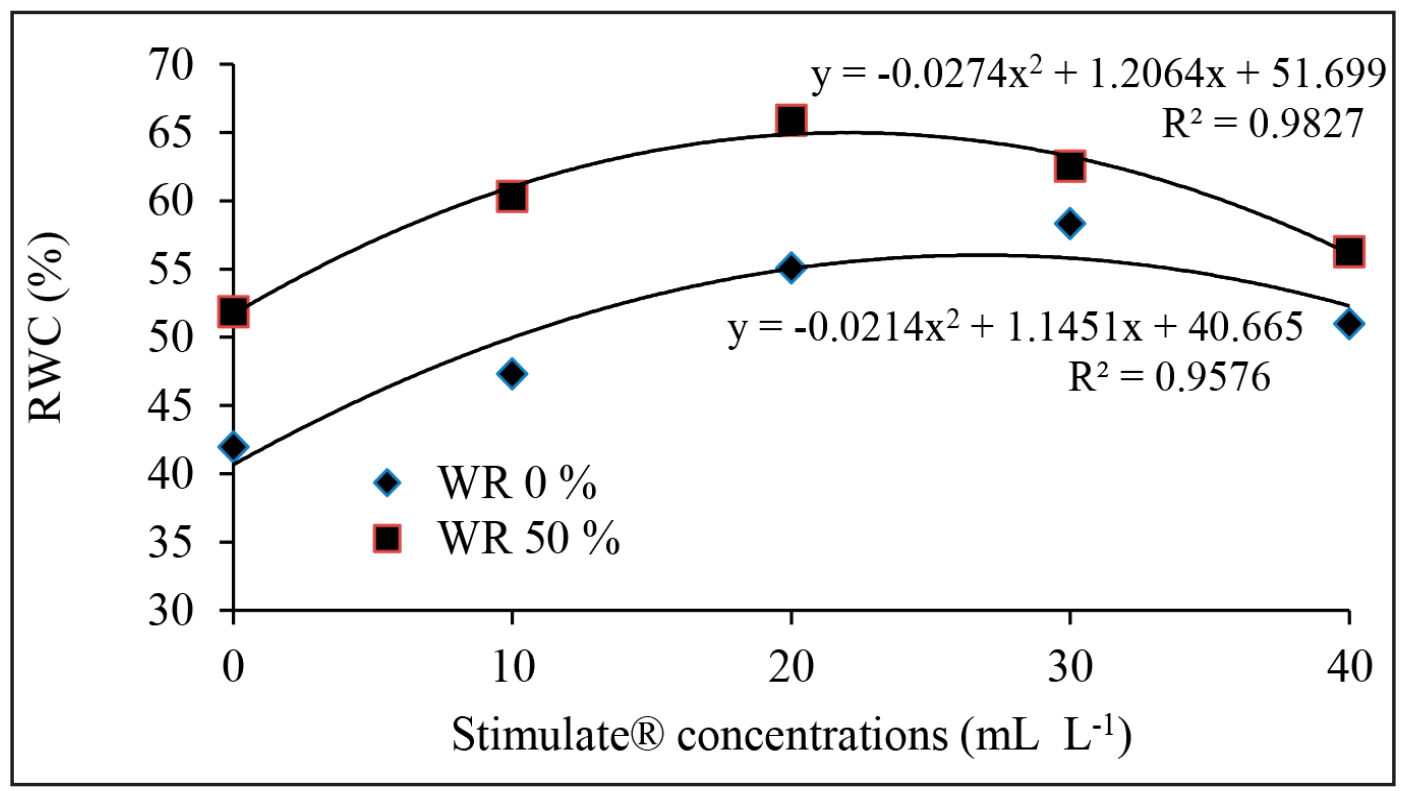

Source: Santos, Cairo, Barbosa, Lacerda, Mafra Neto and Macedo (2019)

Fonte: Santos, Cairo, Barbosa, Lacerda, Mafra Neto e Macedo (2019)

Relative water content partial maintenance, when it occurs along with decrease in leaf water potential, is commonly referred as an efficient physiological response, because it is related to cell turgor maintenance, providing greater plant tolerance to water stress (PRYOR; EAMUS, 1999; TAIZ et al., 2017). Metabolic performance, as well as shoot and root expansion, can also be improved by maintaining cell turgor (CARVALHO, 2005). Even if the osmotic adjustment fails to prevent a plant growth rate drop, it helps maintain physiological processes, although at low rates (AROCA, 2012), thus preserving tissues integrity aiming at a rapid growth rate recovery after water stress overcoming (PALLARDY, 2008). According to Sanches (2000), the use of bio-stimulant, both before and during stress, can helps to mitigate harmful effects of climatic adversities.

The interaction (C) $\mathrm{x}(\mathrm{WR})$ caused significant effects on net photosynthesis (Table 1) in plants under WR 0\% and 100\%. In these irrigation regimes, the highest photosynthesis rates were 21.13 and $21.20 \mu \mathrm{mol} \mathrm{m}^{-2} \mathrm{~s}^{-1}$, in plants sprayed with Stimulate ${ }^{\circledR} 21.57$ and $14.19 \mathrm{~mL} \mathrm{~L}^{-1}$, respectively. These photosynthesis rates were $21.54 \%$ and $9.71 \%$ higher than, respectively, those of plants not sprayed with Stimulate ${ }^{\circledR}$ (Figure 3).

Some characteristics of the growth regulator mix should be considered for the evaluation of photosynthesis in plants sprayed with Stimulate ${ }^{\circledR}$. Indolbutyric acid (IBA), for example, it has been reported to be influential on plant responses to drought by regulating its photosynthetic apparatus and chloroplast structure (TOGNETTI; MÜHLENBOCK; VAN BREUSEGEM, 2011). Transgenic plants of tomato have shown an increased maximum electron transport rate and photochemical quenching under dehydration conditions, indicating the influence of auxin signaling on photosynthesis and plant morphology (EHLERT et al., 2008). Li 
and $\mathrm{Xu}$ (2014) investigated the effects of exogenous hormones on photosynthesis as well as the stomatal conductance of ginseng (Panax ginseng) and reported that both exogenous cytokinin and indole-3-acetic acid (IAA) enhanced stomatal conductance, net photosynthetic rate and transpiration rate. Despite a significant number of studies on auxin signaling under abiotic stress, the relationship between auxin biosynthesis and its influence on the photosynthetic machinery under environmental stress remains unclear and warrants further research (GURURANI; MOHANTA; BAE, 2015).

Figure 3 - Net photosynthesis $(A)$ in young plants of Eucalyptus urophylla, clone AEC 144, sprayed with different Stimulate ${ }^{\circledR}$ concentrations, under non-irrigated (WR 0\%) and WR $100 \%$ regimes.

Figura 3 - Fotossíntese líquida $(A)$ em plantas jovens de Eucalyptus urophylla, clone AEC 144, pulverizadas com Stimulate ${ }^{\circledR}$ em diferentes concentrações, sob regimes não irrigado (WR 0\%) e WR 100\%.

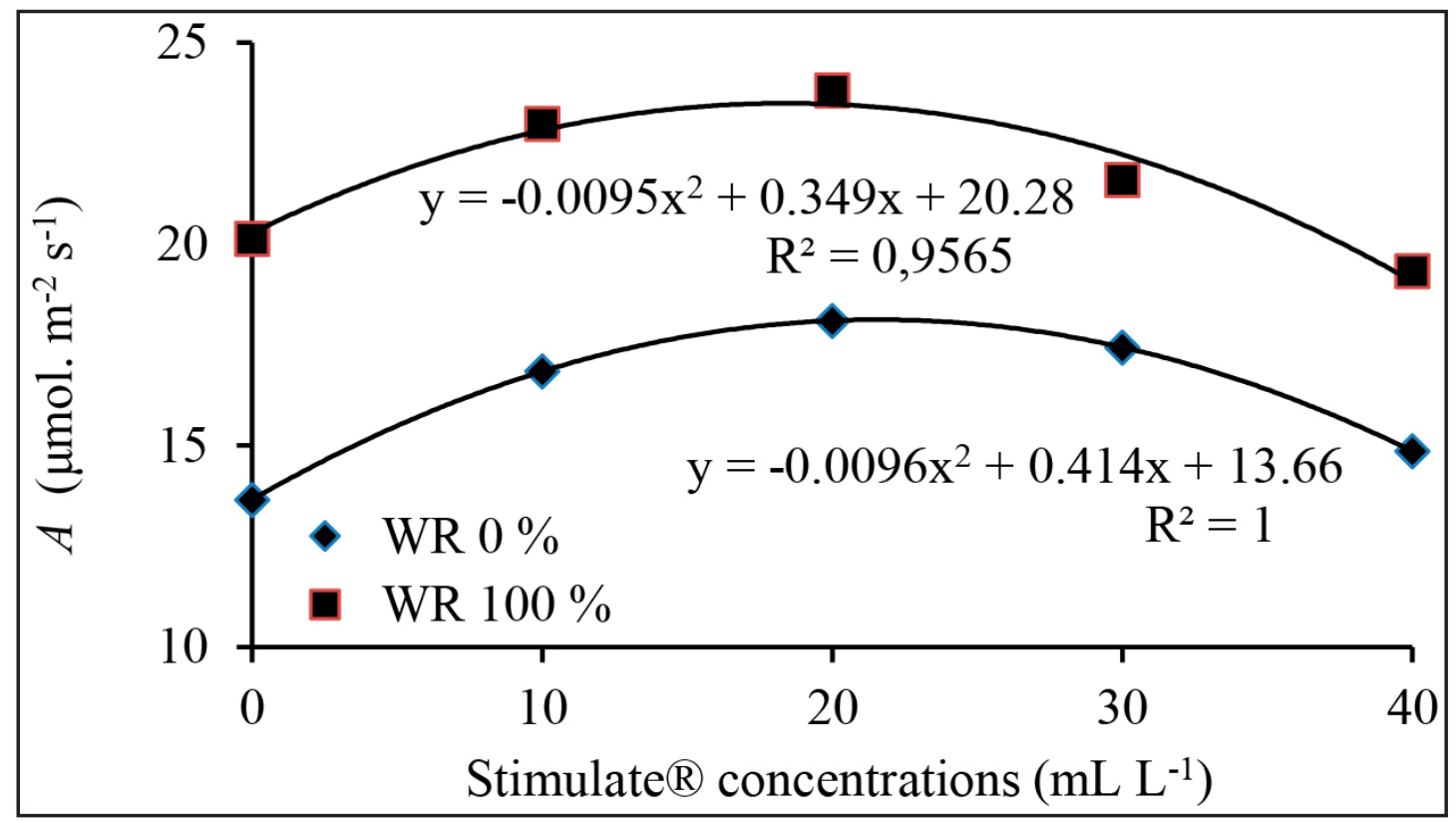

Source: Santos, Cairo, Barbosa, Lacerda, Mafra Neto and Macedo (2019)

Fonte: Santos, Cairo, Barbosa, Lacerda, Mafra Neto e Macedo (2019)

The short-term application of gibberellic acid $\left(\mathrm{GA}_{3}\right)$ in soybean and broad bean plants resulted in increased net photosynthesis, increased stomatal conductance, improved photosynthetic oxygen evolution, and increased carboxylation efficiency (YUAN; XU, 2001). Improved photosynthesis in these plants was attributed to the increased activity and content of Rubisco. In contrast, Dijkstra et al. (1990) investigated the relationship between relative growth rate and endogenous $\mathrm{GA}_{3}$ in two inbred lines of Plantago major plants producing enhanced and reduced levels of $\mathrm{GA}_{3}$, and reported that although $\mathrm{GA}_{3}$ treatment promoted the vegetative growth, the chlorophyll a content and photosynthetic activity per unit leaf area were reduced, indicating the possible involvement of some other regulatory factors.

The role for cytokinins in conferring abiotic stress tolerance in higher plants is presumably via modulating the regulatory mechanism of photosynthetic processes (RIVERO; SHULAEV; BLUMWALD, 2009; RIVERO et al., 2010). Cytokinin-treated maize plants submitted to drought revealed that the electron-donating capacity of photosystem II and the 
photosynthetic performance were increased while electron transport to the acceptor side of photosystem II was reduced with the application of cytokinins (SHAO; WANG; SHANGGUAN, 2009).

A deeper discussion on the auxin/GA /cytokinins and photosynthesis relationships is unfortunately not simple, due to the still scarce knowledge on the role of hormones in photosynthetic processes, especially in plants under water-limited conditions. A definite conclusion still awaits further and more detailed researches, in order to have a better insight of plant drought tolerance mechanisms in plants.

Compared with the height in non-sprayed plants, the increasing concentration of Stimulate $^{\circledR}$ in sprayed plants provided higher plant height both in WR $100 \%$ and WR $0 \%$ irrigation regimes (Figure 4). The growth increasing provided by Stimulate ${ }^{\circledR}$ is an expected response, given the known effects of hormones such as auxins, gibberellins and cytokinins on plant growth (LI; XU, 2014; GURURANI; MOHANTA; BAE, 2015). On the other hand, the effect on height in plants sprayed with Stimulate ${ }^{\circledR}$ under non-irrigated conditions (WR $0 \%$ ) is surprisingly positive, becoming an alternative way to mitigate negative effects of water deficit on plant growth.

Figure 4 - Height of Eucalyptus urophylla young plants, clone AEC 144, sprayed with different Stimulate ${ }^{\circledR}$ concentrations, under non-irrigated (WR 0\%) and WR 100\% regimes.

Figura 4 - Altura de plantas jovens de Eucalyptus urophylla, clone AEC 144, pulverizadas com Stimulate ${ }^{\circledR}$ em diferentes concentrações, sob regimes não irrigado (WR 0\%) e WR 100\%.

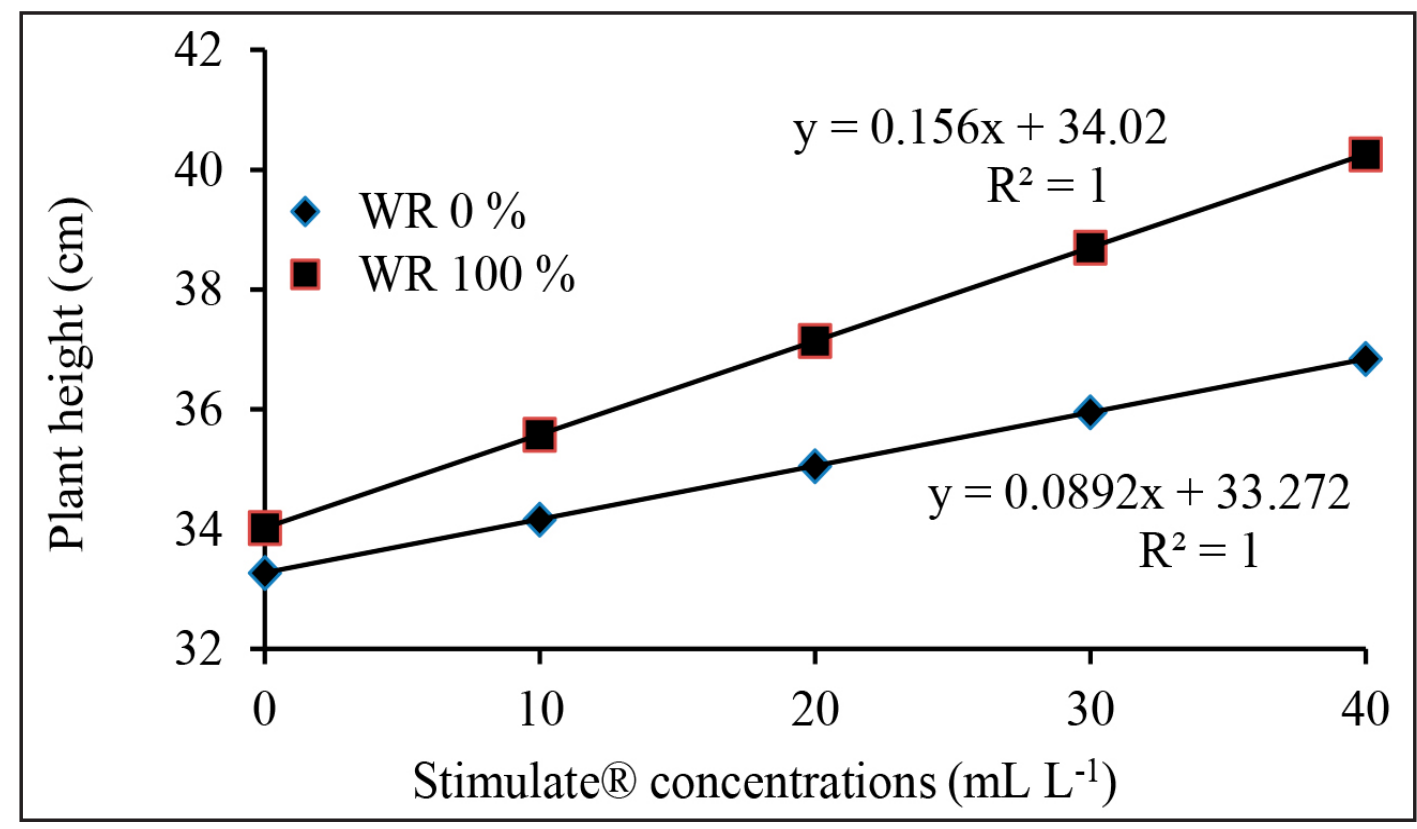

Source: Santos, Cairo, Barbosa, Lacerda, Mafra Neto and Macedo (2019)

Fonte: Santos, Cairo, Barbosa, Lacerda, Mafra Neto e Macedo (2019)

Referring to main root length, compared with non-sprayed plants, the increasing concentration of Stimulate ${ }^{\circledR}$ in sprayed plants improved root expansion in both WR $50 \%$ and WR $0 \%$ irrigation regimes. In non-irrigated plants, however, the positive effect of increasing Stimulate ${ }^{\circledR}$ concentration on root growth occurred only up to $27.37 \mathrm{ml} \mathrm{L}^{-1}$ (estimated concentration) (Figure 5). 
Figure 5 - Main root length in young plants of Eucalyptus urophylla, clone AEC 144, sprayed with different Stimulate ${ }^{\circledR}$ concentrations, under non-irrigated (WR 0\%) and WR 50\% regimes.

Figura 5 - Comprimento da raiz principal em plantas jovens de Eucalyptus urophylla, clone AEC 144, pulverizadas com Stimulate ${ }^{\circledR}$ em diferentes concentrações, sob regimes não irrigado (WR $0 \%)$ e WR $50 \%$.

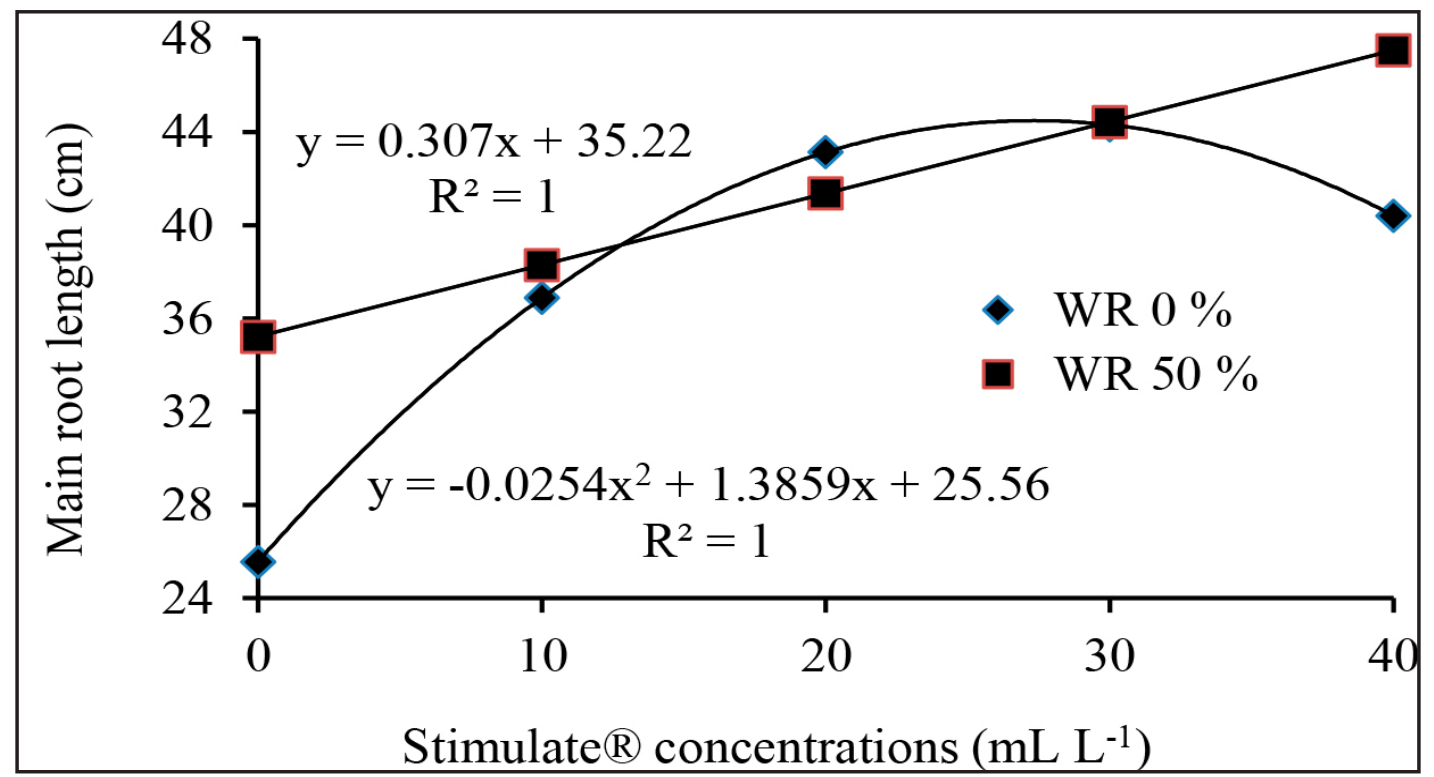

Source: Santos, Cairo, Barbosa, Lacerda, Mafra Neto and Macedo (2019)

Fonte: Santos, Cairo, Barbosa, Lacerda, Mafra Neto e Macedo (2019)

\section{Conclusion}

Under water deficit, plants sprayed with increased Stimulate ${ }^{\circledR}$ concentrations up to 30 $\mathrm{mL} \mathrm{L}^{-1}$, compared with non-sprayed plants, decrease leaf water potential concomitantly with the relative water content partial maintenance, suggesting ability for osmotic adjustment. Under severe water deficit, net photosynthesis, plant height and main root length may be enhanced by Stimulate ${ }^{\circledR}$ although despite some restrictions for concentrations above $20 \mathrm{~mL} \mathrm{~L}^{-1}$. These results lead us to conclude that the use of Stimulate ${ }^{\circledR}$ can be a viable option to mitigate negative water stress physiological effects in young plants of Eucalyptus urophylla, clone AEC 144, helping to partially maintain plant growth under water-limited conditions.

\section{References}

ALBAUGH, J. M.; DYE, P. J.; KING, J. S. Eucalyptus and water use in South Africa. International Journal of Forestry Research, London, v. 2013, p. 1-11, 2013.

AROCA, R. Plant Responses to Drought Stress. From Morphological to Molecular Features. Berlin: Springer-Verlag, 2012. 466 p.

BRUNNER, I. et al. How tree roots respond to drought. Frontiers in Plant Science, Lausanne, v. 6, p. 1-16, 2015.

CARVALHO, C. J. R. Respostas de plantas de Schizolobium amazonicum (S. parahyba var: 
amazonicum) e Schizolobium parahyba (Schizolobium parahybum) à deficiência hídrica. Revista Árvore, Viçosa, MG, v. 29, n. 6, p. 907-914, 2005.

CLAEYS, H.; INZÉ, D. The agony of choice: how plants balance growth and survival under water-limiting conditions. Plant Physiology, Rockville, v. 162, n. 4, p. 1768-1779, 2013.

COSTA E SILVA, F. et al. Responses to water stress in two Eucalyptus globulus clones differing in drought tolerance. Tree Physiology, Oxford, v. 24, p. 1165-1172, 2004.

DANTAS, A. C. V. L. et al. Effect of gibberellic acid and the biostimulant Stimulate ${ }^{\circledR}$ on the initial growth of tamarind. Revista Brasileira de Fruticultura, Jaboticabal, v. 34, n. 1, p. 8-14, 2012.

DIJKSTRA, P.; REEGEN, H.; KUIPER, P. J. Relation between relative growth rate, endogenous gibberellins, and the response to applied gibberellic acid for Plantago major. Physiologia Plantarum, Lund, v. 79, n. 4, p. 629-634, 1990.

EHLERT, B. et al. The paramutated SULFUREA locus of tomato is involved in auxin biosynthesis. Journal of Experimental Botany, Oxford, v. 59, n. 13, p. 3635-3647, 2008.

EMBRAPA. Centro Nacional de Pesquisa de Solos. Manual de métodos de análise de solo. 2. ed. Rio de Janeiro: EMBRAPA; CNPS, 1997. 212 p. (Documentos, n. 1).

FERNANDES, E. T.; CAIRO, P. A. R.; NOVAES, A. B. Respostas fisiológicas de clones de eucalipto cultivados em casa de vegetação sob deficiência hídrica. Ciência Rural, Santa Maria, v. 45, n. 1, p. 29-34, 2015.

GURURANI, M. A.; MOHANTA, T. K.; BAE, H. Current understanding of the interplay between phytohormones and photosynthesis under environmental stress. International Journal of Molecular Sciences, Basel, v. 16, n. 8, p. 19055-19085, 2015.

LAPLAZE, L. et al. Cytokinins acts directly on lateral root founder cells to inhibit root initiation. Plant Cell, Berkeley, v. 19, n. 12, p. 3889-3900, 2007.

LI, X.; XU, K. Effects of exogenous hormones on leaf photosynthesis of Panax ginseng. Photosynthetica, Prague, v. 52, n. 1, p. 152-156, 2014.

OLIVEIRA JÚNIOR, O. A.; CAIRO, P. A. R.; NOVAES, A. B. Características morfofisiológicas associadas à qualidade de mudas de Eucalyptus urophylla produzidas em diferentes substratos. Revista Árvore, Viçosa, MG, v. 35, n. 6, p. 1173-1180, 2011.

PALLARDY, S. G. Physiology of woody plants. $3^{\text {th }}$ ed. Oxford: Elsevier, 2008. 454 p.

POORTER, H. et al. Biomass allocation to leaves, stems and roots: meta-analyses of inters pecific variation and environmental control. New Phytologist, Lancaster, v. 193, n. 1, p. 30-50, 2012.

PRYOR, L. D.; EAMUS, D. Seasonal changes in leaf water characteristics of Eucalyptus tetrodonta and Terminalia ferdinandiana saplings in a northern Australian savana. Australian Journal of Botany, Melbourne, v. 47, n. 4, p. 587-599, 1999.

Ribeiro, A. C.; GUimarÃeS, P. T. G.; AlVAREZ, V. H. Recomendações para o uso de corretivos e fertilizantes em Minas Gerais: 5ª aproximação. Viçosa, MG: CFSEMG; UFV, 1999. 359 p.

RIVERO, R. M. et al. Enhanced cytokinin synthesis in tobacco plants expressing PSARK: IPT prevents the degradation of photosynthetic protein complexes during drought. Plant and Cell Physiology, Oxford, v. 51, n. 11, p. 1929-1941, 2010.

RIVERO, R. M.; SHULAEV, V.; BLUMWALD, E. Cytokinin-dependent photorespiration and the protection of photosynthesis during water deficit. Plant Physiology, Rockville, v. 150, n. 
3, p. 1530-1540, 2009.

SAITO, T. et al. Variations in transpiration rate and leaf cell turgor maintenance in saplings of deciduous broad-leaved tree species common in cool temperate forests in Japan. Tree Physiology, Oxford, v. 23, p. 59-66, 2003.

SANCHES, F. R. Aplicação de biorreguladores vegetais: aspectos fisiológicos e aplicações práticas na citricultura mundial. Jaboticabal: Funep, 2000. 160 p.

SANTOS, C. M. G. Ação de bioestimulante na germinação de sementes, vigor de plântulas e crescimento do algodoeiro. Salvador: Universidade Federal da Bahia, 2004. 61 p.

SCHOLANDER, P. F. et al. Sap pressure in vascular plants. Science, Washington, v. 148, n. 3668, p. 339-346, 1965.

SHAO, R.; WANG, K.; SHANGGUAN, Z. Cytokinin-induced photosynthetic adaptability of Zea mays L. to drought stress associated with nitric oxide signal: Probed by ESR spectroscopy and fast OJIP fluorescence rise. Journal of Plant Physiology, Amsterdam, v. 167, n. 6, p. 472$479,2009$.

SILVA, W. et al. Condutância estomática de Eucalyptus citriodora e E. grandis, em resposta a diferentes níveis de água no solo e de convivência com Brachiaria brizantha Stapf. Bragantia, Campinas, v. 57, n. 2, p. 339-347, 1998.

TAIZ, L. et al. Fisiologia e desenvolvimento vegetal. 6. ed. Porto Alegre: Artmed, 2017. 858 p.

TANIMOTO, E. Regulation of root growth by plant hormones - roles for auxin and gibberellin. Critical Reviews in Plant Sciences, London, v. 24, n. 4, p. 249-265, 2005.

TOGNETTI, V.; MÜHLENBOCK, P.; VAN BREUSEGEM, F. Stress homeostasis - the redox and auxin perspective. Plant, Cell and Environment, Glasgow, v. 35, n. 2, p. 321-333, 2011.

VENTURIN, N. et al. Histórico. In: VALE, A. B. et al. Eucaliptocultura no Brasil: silvicultura, manejo e ambiência. Viçosa, MG: SIF, 2014. p. 17-37.

WEATHERLEY, P. E. Studies in the water relations of the cotton plant. I. The field measurement of water deficit in leaves. New Phytologist, Lancaster, v. 49, n. 1, p. 81-97, 1950.

WHITEHEAD, D.; BEADLE, C. L. Physiological regulation of productivity and water use in Eucalyptus: a review. Forest Ecology and Management, Amsterdam, v. 193, p. 113-140, 2004.

YUAN, L.; XU, D. Stimulation effect of gibberellic acid short-term treatment on leaf photosynthesis related to the increase in Rubisco content in broad bean and soybean. Photosynthesis Research, Basel, v. 68, n. 1, p. 39-47, 2001. 